\title{
Catalytic desulfurization of thiophene on H-ZSM5 using alkanes as co-reactants
}

\author{
Sara Y. Yu ${ }^{\text {a }}$, Toshio Waku ${ }^{\text {a,b }}$, Enrique Iglesia ${ }^{\mathrm{a}, *}$ \\ a Department of Chemical Engineering, University of California at Berkeley, 201 Gilman Hall \#1462, Berkeley, CA 94720, USA \\ ${ }^{\mathrm{b}}$ Central Technical Research Laboratory, Nippon Mitsubishi Oil Corporation, Yokohama 231-0815, Japan
}

Received 22 May 2002; received in revised form 30 August 2002; accepted 6 September 2002

\begin{abstract}
Propane, $n$-hexane, $n$-decane, and hydrogen were used as co-reactants in the desulfurization of thiophene catalyzed by H-ZSM5 at $673 \mathrm{~K}$. These co-reactants lead to hydrogen-rich intermediates, which are required for the removal of unsaturated fragments formed in thiophene decomposition reactions. Thiophene desulfurization rates increased with increasing alkane chain size, suggesting that the availability of hydrogen-rich intermediates increases with increasing alkane reactivity. Desulfurization rates with alkane co-reactants were significantly higher than those achieved with hydrogen. Sulfur is predominately removed as hydrogen sulfide ( $>80 \%$ S-selectivity) in the presence of alkane co-reactants, but much lower hydrogen sulfide selectivities were obtained when hydrogen was used and when thiophene decomposed in the absence of any co-reactants. The presence of thiophene did not alter the nature of the cracking, dehydrogenation, oligomerization, and cyclization pathways typical of alkane reactions or the overall rates of propane conversion on H-ZSM5. The selectivity for alkane conversion to aromatics, however, increased when alkane reactions occur concurrently with thiophene desulfurization, indicating that thiophene-derived intermediates contribute to the formation of aromatics by scavenging alkene intermediates formed from the alkane co-reactants. The higher alkene/alkane ratios observed during alkane reactions in the presence of thiophene are consistent with the scavenging of hydrogen-rich intermediates by thiophene-derived species via reactions that form aromatic molecules containing carbon atoms from both alkane and thiophene reactants.
\end{abstract}

(C) 2002 Elsevier Science B.V. All rights reserved.

Keywords: Thiophene desulfurization; Alkane dehydrogenation; H-ZSM5

\section{Introduction}

The desulfurization of thiophene using propane molecules as co-reactants was recently reported on H-ZSM5 and cation-exchanged H-ZSM5 catalysts $[1,2]$. In this coupling reaction, propane provides adsorbed hydrogen and hydrogen-rich alkenes required for the removal of unsaturated adsorbed species

\footnotetext{
* Corresponding author. Tel.: +1-510-642-9673; fax: +1-510-642-4778.

E-mail address: iglesia@cchem.berkeley.edu (E. Iglesia).
}

formed during thiophene desulfurization on Bronsted acid sites. Thiophene-derived intermediates desorb to form hydrocarbons and hydrogen sulfide selectively during propane-thiophene reactions, without the direct involvement of gas phase $\mathrm{H}_{2}$ molecules formed during concurrent propane dehydrogenation and dehydrocyclodimerization reactions. These reaction pathways were confirmed using ${ }^{13} \mathrm{C}$ and ${ }^{2} \mathrm{H}$ isotopic tracer studies $[3,4]$. Previous studies have shown that hydrodesulfurization of thiophene can also be carried out using hydrogen on cation-exchanged zeolites [1,2,5-11]. 
Here, we extend these previous studies to reactions of higher alkanes with thiophene in order to probe the effects of alkane size and reactivity on the rate, selectivity, and deactivation behavior of thiophene desulfurization reactions. $n$-Hexane and $n$-decane were chosen because, in contrast with propane, they undergo $\beta$-scission and cyclization without requiring chain growth. The reaction pathways of these larger alkanes are typical of those prevalent during catalytic cracking processes, in which thiophene desulfurization can also occur and lead to the consequent formation of hydrogen sulfide and organosulfur compounds larger than thiophene [12-16].

\section{Experimental methods}

Na-ZSM5 (Zeochem, Si/Al = 14.5) was exchanged three times with a $0.25 \mathrm{M} \mathrm{NH}_{4} \mathrm{NO}_{3}$ (Aldrich, $99.999 \%$ ) solution at $353 \mathrm{~K}$ for $16 \mathrm{~h}$. After each exchange, the slurry was filtered and washed with deionized water in order to obtain $\mathrm{NH}_{4}$-ZSM5. $\mathrm{NH}_{4}$-ZSM5 was treated in ambient air at $398 \mathrm{~K}$ overnight and then at $773 \mathrm{~K}$ in flowing dry air (Airgas, zero grade) for $20 \mathrm{~h}$ to form H-ZSM5. The synthesis and characterization of the H-ZSM5 samples have been reported elsewhere [17-19].

H-ZSM5 samples were treated in flowing dry air (Airgas, zero grade) at $773 \mathrm{~K}$ for $1 \mathrm{~h}$ before catalytic reactions. Catalytic rate and selectivity measurements were carried out at 673 or $773 \mathrm{~K}$ using a tubular flow reactor with plug-flow hydrodynamics. Thiophene (1 kPa, Aldrich, >99\%) was added to a propane-He stream $(20 \mathrm{kPa}$, Praxair, certified mixture) using a liquid metering pump (Cole-Parmer 74900). Thiophene/ $n$-hexane $(1 \mathrm{kPa} / 20 \mathrm{kPa} ; n$-hexane, Aldrich, >99\%) and thiophene $/ n$-decane $(1 \mathrm{kPa} / 6 \mathrm{kPa}$ or $12 \mathrm{kPa} ; n$-decane, Aldrich, >99\%) reactants were introduced as premixed liquids into a flowing $\mathrm{He}$ stream using the same liquid metering pump. The two $n$-decane partial pressures $(6$ and $12 \mathrm{kPa})$ used were meant to provide a comparison with propane (at $20 \mathrm{kPa}$ ) and with $n$-hexane $(20 \mathrm{kPa})$ at their respective equivalent "carbon" (or $-\mathrm{CH}_{2}-$ ) partial pressures. All liquid reactants were vaporized immediately upon injection and transferred into the reactor and the analytical system through heated lines kept at $403 \mathrm{~K}$. The reactant conversion levels were changed by varying the reactant space velocity or by allowing deactivation to proceed with increasing time on stream. The effects of conversion on reaction selectivity were independent of which one of the two methods was used in order to change the reactant conversion level. Deactivation rates are reported as first-order rate constants, obtained from the exponential decay in rate with time on stream expected from first-order site deactivation processes.

Reactant and product concentrations in the reactor effluent were measured by gas chromatography (Hewlett-Packard 6890) using capillary (HP-1 crosslinked methyl silicone, $50 \mathrm{~m} \times 0.32 \mathrm{~mm}, 1.05 \mu \mathrm{m}$ film) and packed columns (Hayesep-Q, 80/100 mesh, $10 \mathrm{ft} \times 0.125 \mathrm{in}$.) and flame ionization and thermal conductivity detectors. Product identifications based on elution sequence were confirmed by mass spectrometric analysis after similar chromatographic separation protocols. Sulfur compounds were identified using a GC-MS system equipped with the same capillary column and with an electron-impact mass selective detector (Hewlett-Packard 5971). $\mathrm{H}_{2} \mathrm{~S}$ was measured and quantified using TCD areas relative to $\mathrm{Ar}$ (internal standard). Reaction rates are reported as turnover rates (reactant molar conversion rate/g-atom Al-s). Product selectivities are reported on a carbon basis as the percentage of the total carbon atoms converted in the reactant stream (alkane or alkane-thiophene) appearing as a given product. Sulfur selectivities are reported similarly, but based on the number of sulfur atoms present in the reacted thiophene molecules.

\section{Results and discussion}

Thiophene desulfurization reactions were studied using propane, $n$-hexane, and $n$-decane as co-reactants. These results are reported as thiophene desulfurization first-order rate constants, because the high thiophene conversions attained required that reaction rates be described using rigorous integral plug-flow hydrodynamic models. Independent kinetic studies have confirmed this first-order dependence of desulfurization reactions on thiophene concentration. These rate constants are reported in Table 1 for reactions of thiophene with $n$-decane (at $673 \mathrm{~K}$ ), $n$-hexane (at $673 \mathrm{~K}$ ), or propane (at $773 \mathrm{~K}$ ). At similar $-\mathrm{CH}_{2}$ - effective pressures, desulfurization rate constants were higher with $n$-decane $(6 \mathrm{kPa})$ than with propane co-reactants 
Table 1

Comparison of pure alkane and alkane-thiophene reactions on H-ZSM5 ( $\mathrm{Si} / \mathrm{Al}=14.5)$

\begin{tabular}{|c|c|c|c|c|c|c|c|c|c|}
\hline Reactants & $\begin{array}{l}\mathrm{He} / \\
\mathrm{C}_{4} \mathrm{H}_{4} \mathrm{~S} \\
\end{array}$ & $\mathrm{C}_{3} \mathrm{H}_{8}$ & $\begin{array}{l}\mathrm{C}_{3} \mathrm{H}_{8} / \\
\mathrm{C}_{4} \mathrm{H}_{4} \mathrm{~S} \\
\end{array}$ & $\mathrm{C}_{6} \mathrm{H}_{14}$ & $\begin{array}{l}\mathrm{C}_{6} \mathrm{H}_{14} / \\
\mathrm{C}_{4} \mathrm{H}_{4} \mathrm{~S}\end{array}$ & $\mathrm{C}_{10} \mathrm{H}_{22}$ & $\begin{array}{l}\mathrm{C}_{10} \mathrm{H}_{22} / \\
\mathrm{C}_{4} \mathrm{H}_{4} \mathrm{~S}\end{array}$ & $\mathrm{C}_{10} \mathrm{H}_{22}$ & $\begin{array}{l}\mathrm{C}_{10} \mathrm{H}_{22} \\
\mathrm{C}_{4} \mathrm{H}_{4} \mathrm{~S} \\
\end{array}$ \\
\hline Reaction temperature $(\mathrm{K})$ & 773 & 773 & 773 & 673 & 673 & 673 & 673 & 673 & 673 \\
\hline Reactants (alkane/thiophene) (kPa) & $0 / 1$ & $20 / 0$ & $20 / 1$ & $20 / 0$ & $20 / 1$ & $6 / 0$ & $6 / 1$ & $12 / 0$ & $12 / 1$ \\
\hline $\begin{array}{l}\text { Alkane conversion to hydrocarbons } \\
(\%)\end{array}$ & - & 18.5 & 9.6 & 63.0 & 60.1 & 38.8 & 37.3 & 34.2 & 33.6 \\
\hline $\begin{array}{l}\text { Hydrocarbon formation rate } \\
\left.\text { (per } \mathrm{Al} 10^{-3} \mathrm{~s}^{-1}\right)\end{array}$ & - & 1.4 & 1.5 & 22.9 & 21.9 & 47.1 & 43.3 & 72.0 & 71.3 \\
\hline $\begin{array}{l}\text { Hydrocarbon deactivation } \\
\text { rate constant }\left(k_{\mathrm{d}}\right)\left(\mathrm{h}^{-1}\right)\end{array}$ & - & $<0.001$ & 0.055 & 0.014 & 0.18 & 0.0090 & 0.22 & 0.026 & 0.34 \\
\hline Thiophene conversion $(\%)$ & 9.2 & - & 77.9 & - & 89.1 & - & 50.0 & - & 56.6 \\
\hline 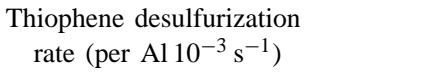 & 0.063 & - & 0.61 & - & 1.6 & - & 3.7 & - & 10.0 \\
\hline $\begin{array}{l}\text { Thiophene desulfurization rate } \\
\text { constant }(k)\left(\times 10^{4} \mathrm{~cm}^{3} /(\mathrm{mol} \mathrm{Al}-\mathrm{s})\right)\end{array}$ & 0.015 & - & 0.25 & - & 0.88 & - & 0.90 & - & 3.4 \\
\hline $\begin{array}{l}\text { Desulfurization deactivation } \\
\text { rate constant }\left(k_{\mathrm{d}}\right)\left(\mathrm{h}^{-1}\right)\end{array}$ & 0.18 & - & 0.033 & - & 0.086 & - & 0.090 & - & 0.097 \\
\hline
\end{tabular}

$(20 \mathrm{kPa})\left(0.90 \times 10^{-4} \mathrm{~cm}^{3} /(\mathrm{mol} \mathrm{Al}-\mathrm{s})\right.$ versus $0.25 \times$ $\left.10^{-4} \mathrm{~cm}^{3} /(\mathrm{mol} \mathrm{Al}-\mathrm{s})\right)$, even at the lower temperatures used for the thiophene-decane mixtures $(673 \mathrm{~K}$ versus $773 \mathrm{~K}$ ). Desulfurization rate constants at $673 \mathrm{~K}$ were also higher with $n$-decane $(12 \mathrm{kPa})$ than with $n$-hexane $(20 \mathrm{kPa})$ co-reactants $\left(3.4 \times 10^{-4} \mathrm{~cm}^{3} /(\mathrm{mol} \mathrm{Al}-\mathrm{s})\right.$ versus $\left.0.88 \times 10^{-4} \mathrm{~cm}^{3} /(\mathrm{mol} \mathrm{Al}-\mathrm{s})\right)$.

Hydrocarbon formation rates using pure alkanes and alkane-thiophene mixtures are also shown in Table 1. Hydrocarbon formation rates were not strongly influenced by the presence of thiophene, but the selectivity to aromatics was significantly higher for each alkane when thiophene is present (Table 3 ). The higher reactivity of larger alkanes led to higher rates of $\mathrm{C}-\mathrm{H}$ bond activation and to more readily available hydrogen, hydrogen-rich adsorbed intermediates, and alkenes, all of which provide pathways for the reactive desorption of thiophene-derived unsaturated fragments formed on acid sites. $n$-Hexane and $n$-decane were significantly more effective reactants than propane, even at the lower temperatures used for the reactions of these larger alkanes.

First-order deactivation rate constants are shown in Table 1 for each alkane reactant and for the corresponding alkane-thiophene mixture. Deactivation rate constants for thiophene desulfurization reactions increased with increasing alkane chain size. Deactivation rates for dehydrocyclodimerization reactions also increased with alkane size; they were higher for each alkane reactant when thiophene was present than for the respective pure alkane reactant. Such effects are consistent with the formation of more unsaturated intermediates during thiophene desulfurization and alkane dehydrocyclodimerization reactions as the hydrogen-to-carbon ratio decreases with increasing alkane chain length.

Thiophene desulfurization rate constants at 673 or $773 \mathrm{~K}$ for alkane-thiophene reactant mixtures were also compared to those measured at $773 \mathrm{~K}$ using hydrogen molecules as co-reactants (Table 2). Desulfurization rate constants (at $673 \mathrm{~K}$ ) with $n$-hexane and

Table 2

Comparison of thiophene desulfurization rate constants in the presence of hydrogen or propane at $773 \mathrm{~K}$, and hexane or decane at $673 \mathrm{~K}$ on $\mathrm{H}-Z \mathrm{ZSM} 5\left(773\right.$ or $673 \mathrm{~K}, 1 \mathrm{kPa} \mathrm{C} \mathrm{C}_{4} \mathrm{H}_{4} \mathrm{~S}, 0-200 \mathrm{kPa}$ hydrogen, $20 \mathrm{kPa} \mathrm{C}_{3} \mathrm{H}_{8}, 20 \mathrm{kPa} \mathrm{C}_{6} \mathrm{H}_{14}, 6 \mathrm{kPa} \mathrm{C}_{10} \mathrm{H}_{22}$, or $12 \mathrm{kPa}$ $\mathrm{C}_{10} \mathrm{H}_{22}$, balance $\mathrm{He}$ )

\begin{tabular}{cl}
\hline $\begin{array}{l}\text { Gas phase pressure of } \\
\text { hydrogen source }(\mathrm{kPa})\end{array}$ & $\begin{array}{l}\text { Thiophene desulfurization } \\
\text { rate constant }(k) \\
\left(\times 10^{4} \mathrm{~cm}^{3} /(\mathrm{mol} \mathrm{Al}-\mathrm{s})\right)\end{array}$ \\
\hline $0(773 \mathrm{~K})$ & 0.015 \\
$100\left(\mathrm{H}_{2}\right)(773 \mathrm{~K})$ & 0.032 \\
$200\left(\mathrm{H}_{2}\right)(773 \mathrm{~K})$ & 0.077 \\
$20\left(\mathrm{C}_{3} \mathrm{H}_{8}\right)(773 \mathrm{~K})$ & 0.25 \\
$20\left(\mathrm{C}_{6} \mathrm{H}_{14}\right)(673 \mathrm{~K})$ & 0.88 \\
$6\left(\mathrm{C}_{10} \mathrm{H}_{22}\right)(673 \mathrm{~K})$ & 0.90 \\
$12\left(\mathrm{C}_{10} \mathrm{H}_{22}\right)(673 \mathrm{~K})$ & 3.4 \\
$20\left(\mathrm{C}_{3} \mathrm{H}_{8}\right)(773 \mathrm{~K}) \mathrm{Zn} / \mathrm{H}-\mathrm{ZSM} 5$ & 0.44 \\
\hline
\end{tabular}


$n$-decane as co-reactants are not only greater than those with propane co-reactants, but also much greater than those achieved with $100-200 \mathrm{kPa} \mathrm{H}_{2}$ at $773 \mathrm{~K}$ (Table 2). Even when $\mathrm{Zn}$ cations were exchanged into H-ZSM5 in order to provide hydrogen dissociation sites, $n$-hexane and $n$-decane are significantly more effective hydrogen sources for thiophene desulfurization than hydrogen (Table 2) [1].

The effects of thiophene co-reactants on the products formed from propane, $n$-hexane, and $n$-decane on H-ZSM5 are shown in Table 3. Hydrocarbon selectivities measured with and without thiophene are compared for each alkane in Table 3; these comparisons are presented at similar alkane conversion levels, because primary and secondary reaction path- ways prevalent during alkane reactions can lead to significant effects of reactant conversion and reactor residence time on product distributions. For each alkane, the presence of thiophene led to higher selectivities to aromatic products, as reported previously for propane reactants [3]. Isotopic tracing of reaction products formed from mixtures of thiophene and ${ }^{13} \mathrm{C}$-labeled propane on $\mathrm{H}-\mathrm{ZSM} 5$ and Co/H-ZSM5 showed that these higher aromatics selectivities were only partially caused by the contribution of thiophenic carbons to these aromatic products. The aromatics selectivity of the propane dehydrocyclodimerization reaction itself also increased when thiophene was present as a scavenger for propane-derived hydrogen and hydrogen-rich intermediates [3]. Reactions among

Table 3

Comparison of product selectivities (on a per total carbon basis of both reactants) during pure alkane and alkane-thiophene reactions on H-ZSM5 ( $\mathrm{Si} / \mathrm{Al}=14.5)$

\begin{tabular}{|c|c|c|c|c|c|c|c|c|c|}
\hline Reactants & $\begin{array}{l}\mathrm{He} / \\
\mathrm{C}_{4} \mathrm{H}_{4} \mathrm{~S} \\
\end{array}$ & $\mathrm{C}_{3} \mathrm{H}_{8}$ & $\begin{array}{l}\mathrm{C}_{3} \mathrm{H}_{8} / \\
\mathrm{C}_{4} \mathrm{H}_{4} \mathrm{~S} \\
\end{array}$ & $\mathrm{C}_{6} \mathrm{H}_{14}$ & $\begin{array}{l}\mathrm{C}_{6} \mathrm{H}_{14} / \\
\mathrm{C}_{4} \mathrm{H}_{4} \mathrm{~S} \\
\end{array}$ & $\mathrm{C}_{10} \mathrm{H}_{22}$ & $\begin{array}{l}\mathrm{C}_{10} \mathrm{H}_{22} / \\
\mathrm{C}_{4} \mathrm{H}_{4} \mathrm{~S}\end{array}$ & $\mathrm{C}_{10} \mathrm{H}_{22}$ & $\begin{array}{l}\mathrm{C}_{10} \mathrm{H}_{22} / \\
\mathrm{C}_{4} \mathrm{H}_{4} \mathrm{~S} \\
\end{array}$ \\
\hline Reaction temperature $(\mathrm{K})$ & 773 & 773 & 773 & 673 & 673 & 673 & 673 & 673 & 673 \\
\hline Reactants (alkane/thiophene) (kPa) & $0 / 1$ & $20 / 0$ & $20 / 1$ & $20 / 0$ & $20 / 1$ & $6 / 0$ & $6 / 1$ & $12 / 0$ & $12 / 1$ \\
\hline $\begin{array}{l}\text { Hydrocarbon formation rate } \\
\quad\left(\text { per } \mathrm{Al} 10^{-3} \mathrm{~s}^{-1}\right)\end{array}$ & - & 0.94 & 1.7 & 31.9 & 11.9 & 90.6 & 37.2 & 145.7 & 71.3 \\
\hline $\begin{array}{l}\text { Thiophene desulfurization } \\
\text { rate (per } \mathrm{Al} 10^{-3} \mathrm{~s}^{-1} \text { ) }\end{array}$ & 0.070 & - & 0.63 & - & 1.21 & - & 3.10 & - & 10.0 \\
\hline Alkane conversion to hydrocarbons (\%) & - & 11.2 & 7.9 & 30.9 & 33.6 & 31.9 & 31.8 & 33.0 & 32.6 \\
\hline Thiophene conversion (\%) & 9.6 & - & 69.9 & - & 67.9 & - & 46.6 & - & 56.6 \\
\hline \multicolumn{10}{|l|}{ Selectivity $(\% \mathrm{C})$} \\
\hline $\mathrm{CH}_{4}$ & 0.27 & 25.0 & 17.7 & 0.14 & 0.23 & 0.036 & 0.037 & 0.040 & 0.039 \\
\hline $\mathrm{C}_{2} \mathrm{H}_{4}$ & 1.1 & 34.5 & 21.7 & 3.2 & 3.8 & 2.7 & 2.3 & 2.6 & 2.2 \\
\hline $\mathrm{C}_{2} \mathrm{H}_{6}$ & 0 & 6.9 & 3.9 & 1.2 & 1.8 & 0.3 & 0.3 & 0.3 & 0.2 \\
\hline $\mathrm{C}_{3} \mathrm{H}_{6}$ & 0.45 & 20.1 & 9.9 & 8.7 & 9.8 & 19.7 & 18.0 & 16.4 & 15.2 \\
\hline $\mathrm{C}_{3} \mathrm{H}_{8}$ & 0 & - & - & 32.2 & 30.9 & 14.3 & 13.8 & 14.8 & 14.0 \\
\hline Butenes & 0 & 4.0 & 2.0 & 8.5 & 8.4 & 21.0 & 20.5 & 19.0 & 19.5 \\
\hline Butanes & 0 & 4.7 & 2.1 & 25.6 & 19.5 & 15.7 & 15.2 & 17.6 & 16.9 \\
\hline $\mathrm{C}_{5}-\mathrm{C}_{6}$ & 2.0 & 0.53 & 0.60 & $14.1^{\mathrm{a}}$ & $10.6^{\mathrm{a}}$ & 23.8 & 24.6 & 24.9 & 25.9 \\
\hline $\mathrm{C}_{7}-\mathrm{C}_{8}$ & - & - & - & - & - & 1.4 & 1.4 & 2.2 & 2.3 \\
\hline $\mathrm{C}_{6+}$ aromatics & 4.9 & 4.1 & 34.5 & 5.7 & 13.4 & 1.3 & 3.2 & 2.4 & 3.4 \\
\hline \multicolumn{10}{|l|}{ Alkene/alkane ratios } \\
\hline $\mathrm{C}_{3}$ & - & - & - & 0.27 & 0.32 & 1.38 & 1.30 & 1.11 & 1.09 \\
\hline $\mathrm{C}_{4}$ & - & 0.85 & 0.92 & 0.33 & 0.43 & 1.34 & 1.35 & 1.08 & 1.15 \\
\hline \multicolumn{10}{|l|}{ Sulfur selectivity (\%) } \\
\hline Hydrogen sulfide & 49.1 & - & 90.5 & - & 92.9 & - & 89.8 & - & 95.7 \\
\hline Methylthiophenes & 5.8 & - & 2.8 & - & 3.5 & - & 6.2 & - & 3.4 \\
\hline Dimethylthiophenes & 0 & - & 0.5 & - & 2.0 & - & 3.0 & - & 0.8 \\
\hline Benzothiophene & 45.1 & - & 6.3 & - & 1.6 & - & 1.0 & - & 0.0 \\
\hline
\end{tabular}

\footnotetext{
${ }^{\text {a }}$ Excluding $n$-hexane.
} 
unsaturated products of thiophene and hydrogen-rich intermediates formed from alkanes lead to synergistic effects that increase the rate of both alkane dehydrocyclodimerization and thiophene desulfurization reactions.

The alkene to alkane ratios for $\mathrm{C}_{3}$ and $\mathrm{C}_{4}$ products of alkane and alkane-thiophene reactions are also shown in Table 3. Alkene/alkane ratios are greater when thiophene is present as a co-reactant (Table 3). This indicates that thiophene scavenges hydrogen and hydrogen-rich intermediates, leading to a higher selectivity to unsaturated products.

The various sulfur compounds formed are also shown in Table 3 and reported as sulfur selectivities, defined as the percentage of the sulfur in the converted thiophene appearing within each reaction product.

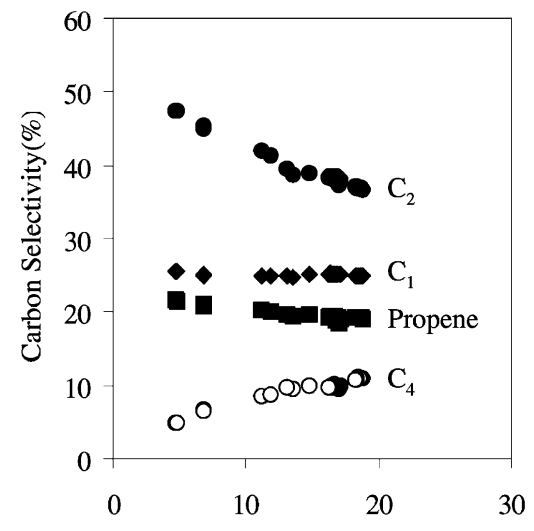

(a) Total Carbon Conversion (\%)

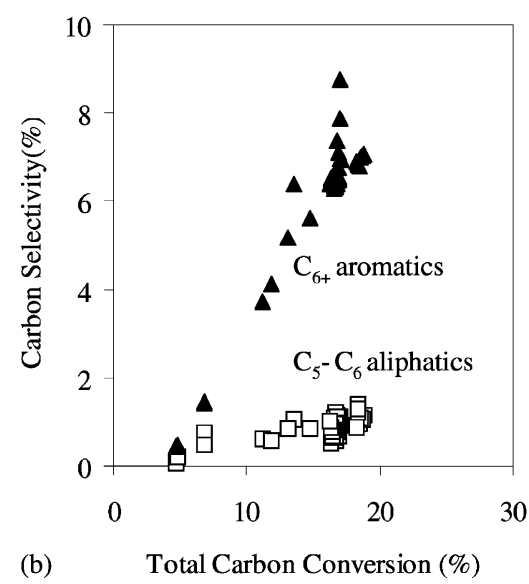

When thiophene is used as the sole reactant, it reacts predominately via bimolecular Diels-Alder reactions to form equimolar amounts of benzothiophene and hydrogen sulfide (Table 3). When alkanes were present as a hydrogen source, the hydrogen sulfide selectivity increased markedly, concurrently with a decrease in the selectivity to larger organosulfur compounds. Thiophene reacts with hydrogen and hydrogen-rich species rather than with other thiophene molecules, leading to the selective formation of hydrogen sulfide.

Detailed product distributions are shown in Figs. 1-3 as a function of alkane or total (alkane + thiophene) reactant conversion for each alkane and alkane-thiophene mixture; in these experiments, the reactant conversion was varied by changing the reactant residence time, or by allowing deactivation

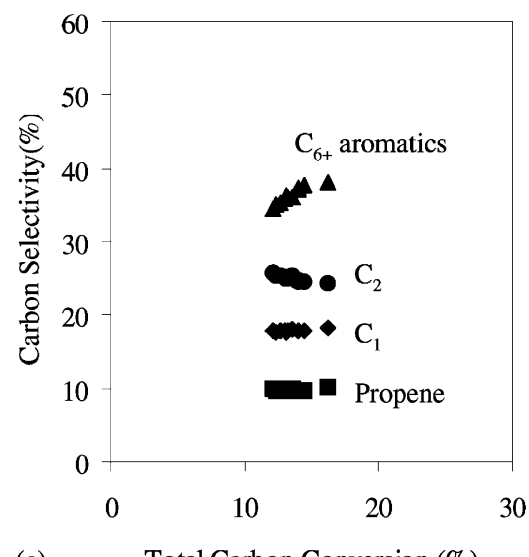

(c)

Total Carbon Conversion (\%)

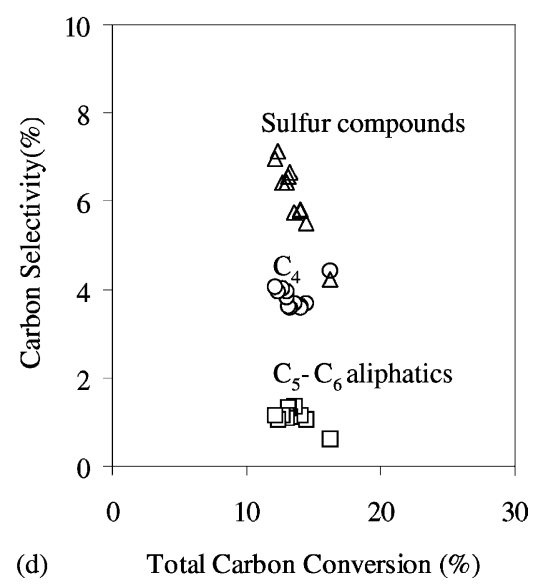

Fig. 1. Product selectivity of ( $\mathrm{a}$ and $\mathrm{b}$ ) propane and (c and d) propane-thiophene reactions on H-ZSM5 ( $\mathrm{Si} / \mathrm{Al}=14.5)$ as a function of total carbon conversion ( $\left(\mathrm{a}\right.$ and b): $773 \mathrm{~K}, 20 \mathrm{kPa} \mathrm{C}_{3} \mathrm{H}_{8}$, balance $\mathrm{He}$; (c and d): $773 \mathrm{~K}, 20 \mathrm{kPa} \mathrm{C}_{3} \mathrm{H}_{8}, 1 \mathrm{kPa} \mathrm{C}_{4} \mathrm{H}_{4} \mathrm{~S}$, balance $\mathrm{He}$ ). 

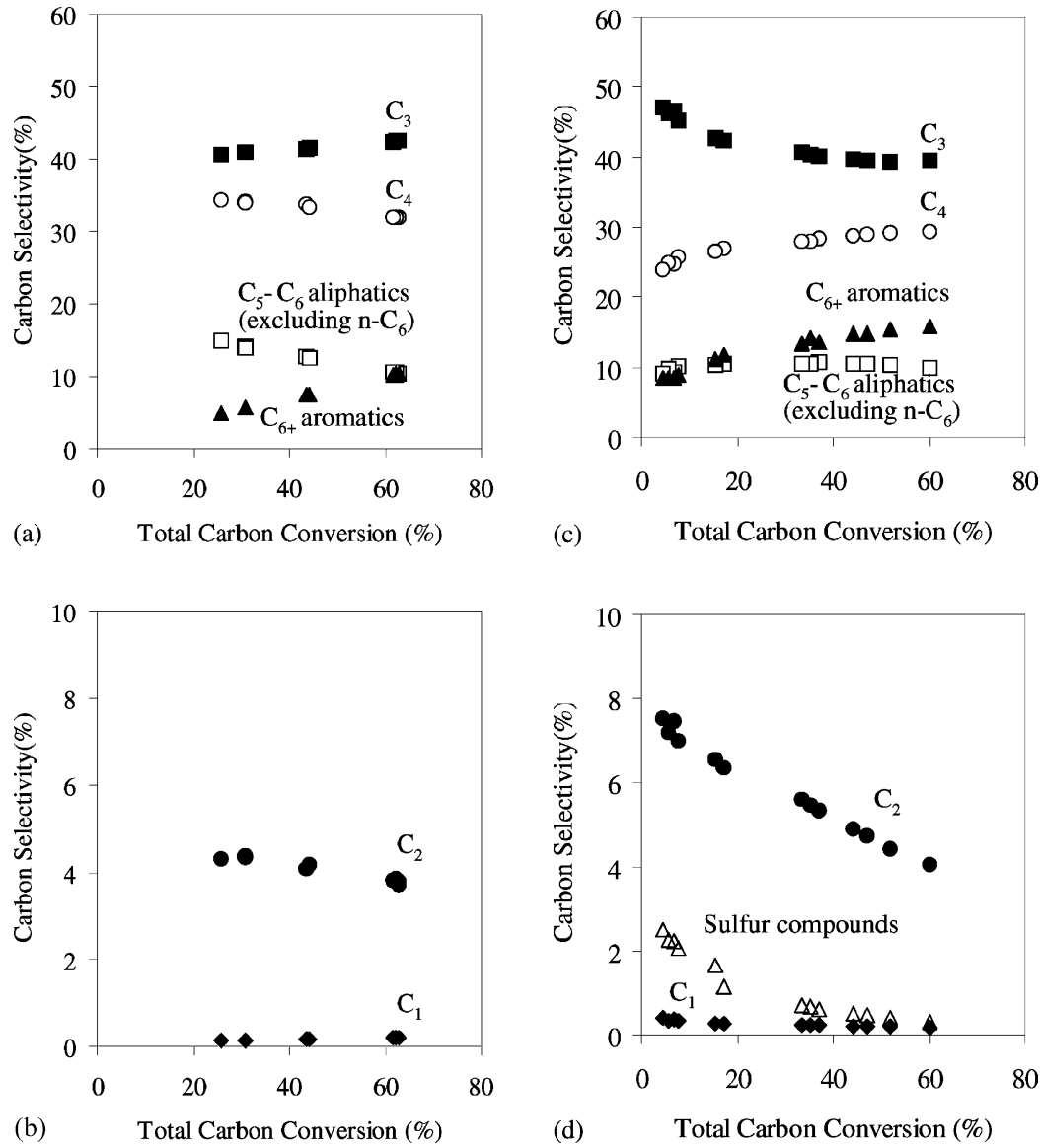

Fig. 2. Product selectivity of ( $\mathrm{a}$ and $\mathrm{b}$ ) hexane and (c and d) hexane-thiophene reactions on H-ZSM5 (Si/Al = 14.5) as a function of total carbon conversion: ((a and b): $673 \mathrm{~K}, 20 \mathrm{kPa} \mathrm{C}_{6} \mathrm{H}_{14}$, balance $\mathrm{He}$; (c and d): $673 \mathrm{~K}, 20 \mathrm{kPa} \mathrm{C}_{6} \mathrm{H}_{14}, 1 \mathrm{kPa} \mathrm{C}_{4} \mathrm{H}_{4} \mathrm{~S}$, balance $\mathrm{He}$ ).

to proceed with increasing time on stream. $\mathrm{C}_{1}-\mathrm{C}_{2}$ products consist of methane, ethene, and ethane. The $\mathrm{C}_{3}$ fraction contains both propene and propane and the $\mathrm{C}_{4}$ products contain butenes and butanes; $\mathrm{C}_{5}-\mathrm{C}_{6}$ aliphatic products consist of pentenes, pentanes, hexenes, and hexanes. The $\mathrm{C}_{6+}$ aromatics fraction contains benzene, toluene, xylenes, as well as traces of higher aromatics. Alkylthiophenes and benzothiophene were the predominant organosulfur compounds.

Product distributions for reactions of pure propane and of propane-thiophene reactants are shown in Fig. 1. At short contact times, $\mathrm{C}_{1}-\mathrm{C}_{2}$ products are formed via direct propane cracking, while propene and hydrogen are formed via propane dehydrogenation steps, as shown in the scheme below.

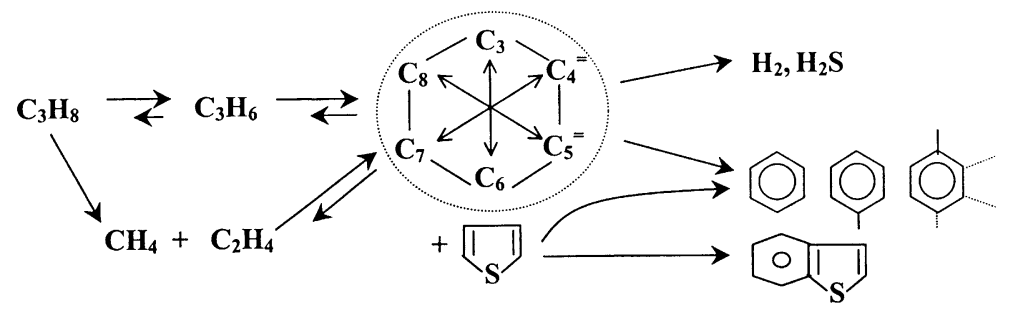



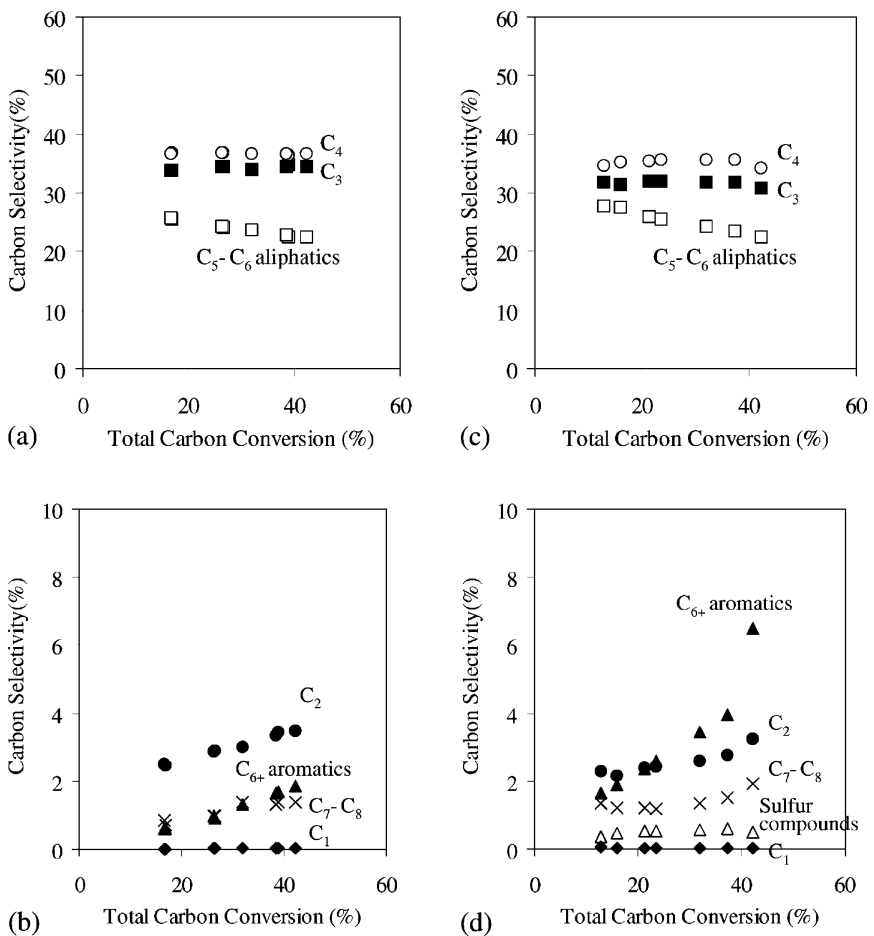

Fig. 3. Product selectivity of ( $\mathrm{a}$ and $\mathrm{b}$ ) decane and ( $\mathrm{c}$ and $\mathrm{d}$ ) decane-thiophene reactions on $\mathrm{H}-\mathrm{ZSM} 5(\mathrm{Si} / \mathrm{Al}=14.5)$ as a function of total carbon conversion: ((a and b): $673 \mathrm{~K}, 6 \mathrm{kPa} \mathrm{C}{ }_{10} \mathrm{H}_{22}$, balance $\mathrm{He}$; (c and d): $673 \mathrm{~K}, 6 \mathrm{kPa} \mathrm{C}_{10} \mathrm{H}_{22}, 1 \mathrm{kPa} \mathrm{C}_{4} \mathrm{H}_{4} \mathrm{~S}$, balance $\mathrm{He}$ ).

$\mathrm{C}_{4}$ and $\mathrm{C}_{6+}$ products become more prevalent at higher conversions, because of their formation via secondary oligomerization and cracking reactions of alkenes. When thiophene was present, the selectivities to $\mathrm{C}_{1}-\mathrm{C}_{2}$, propene, and $\mathrm{C}_{4}$ products were lower, while the selectivity to aromatics was higher (Fig. 1). Alkene intermediates react with thiophene to form aromatics, instead of participating in alternate pathways, such as hydrogenation or cracking, which lead to higher alkane selectivities. Previous studies have shown that the addition of alkenes to ethylthiophene increased its desulfurization reaction rate; this was attributed to the formation of carbocations from the added alkenes [13]. Thiophene does not appear to influence the types of reactions involved in propane conversion, but it reacts with hydrogen-rich intermediates derived from propane and leads to an increase in the overall selectivity for alkane conversion to aromatics.

$\mathrm{C}_{3}$ and $\mathrm{C}_{4}$ hydrocarbons are the predominant initial products of $n$-hexane cracking on H-ZSM 5 at $673 \mathrm{~K}$ (Fig. 2), suggesting that cracking pathways in the reaction scheme proposed above for propane become dominant as a result of the more stable carbocation intermediates available for larger chains. Cracking reactions initially involve direct $\beta$-scission reactions of hexane-derived adsorbed intermediates. $\mathrm{C}_{2}-\mathrm{C}_{4}$ alkene selectivities decreased with increasing conversion, while selectivities to $\mathrm{C}_{2}-\mathrm{C}_{4}$ alkane and $\mathrm{C}_{6+}$ aromatics products increased. The alkenes formed in primary cracking steps are consumed via hydrogenation to form alkanes and via oligomerization/cracking reactions to form aromatics with increasing residence time. Thiophene does not influence the nature of $n$-hexane cracking pathways, but it leads to higher selectivities to aromatics, with a concurrent decrease in the cracking selectivity (to $\mathrm{C}_{3}$ and $\mathrm{C}_{4}$ hydrocarbons), as also observed for propane reactants. It appears that these selectivity changes reflect reactions of unsaturated thiophene-derived fragments with alkenes to form aromatics containing carbon atoms from both thiophene and $n$-hexane as also observed for propane-thiophene mixtures. 
$n$-Decane reactions include multiple cracking events, even at short residence times, suggesting that several $\mathrm{C}-\mathrm{C}$ bonds are cleaved in one surface sojourn. Initial $\beta$-scission along the chain to form $\mathrm{C}_{3}-\mathrm{C}_{6}$ hydrocarbons is followed by sequential secondary cracking of these molecules (Fig. 3), with the ultimate formation of mixtures containing predominately $\mathrm{C}_{3}-\mathrm{C}_{4}$ molecules. As for propane and hexane co-reactants, thiophene addition to $n$-decane did not strongly influence the types of reactions, but it increased slightly the selectivity to aromatics while decreasing the selectivity to $\mathrm{C}_{3}-\mathrm{C}_{4}$ products.

The percentage of the sulfur removed that appears as hydrogen sulfide is shown in Fig. 4a as a function of thiophene conversion for pure thiophene feeds, for hydrogen-thiophene mixtures, and for each alkane-thiophene mixture. $\mathrm{H}_{2} \mathrm{~S}$ selectivities for all alkane-thiophene reactions are significantly higher than for reactions of pure thiophene or of $\mathrm{H}_{2}$-thiophene mixtures (Fig. 4a). During reactions of pure thiophene, bimolecular Diels-Alder pathways lead to the preferential reaction of thiophene-derived fragments with another thiophene to give one hydrogen sulfide molecule and one benzothiophene molecule. Thus, it appears that the rate-controlling step in $\mathrm{H}_{2} \mathrm{~S}$ formation is the transfer of hydrogen from alkane-derived intermediates to unsaturated thiophene-derived fragments, as proposed in previous studies from the effects of hydride transfer agents on desulfurization rates [13] and from theoretical studies of acid-catalyzed thiophene desulfurization [20]. These conclusions are consistent with reports that cracking catalysts with higher hydrogen transfer activity tend to form fewer heavier sulfur compounds in fluid catalytic cracking processes [15].

Alkanes provide the hydrogen atoms required for desorption and desulfurization of these heavier organosulfur compounds, either via direct hydrogen transfer or via reactions of stranded unsaturated species with hydrogen-rich alkenes. The scavenging of thiophene-derived unsaturated intermediates using adsorbed hydrogen and hydrogen-rich intermediates or gas phase alkenes decreases the rate of bimolecular Diels-Alder reactions; this leads in turn to the formation of larger organosulfur compounds and to low $\mathrm{H}_{2} \mathrm{~S}$ selectivity. Fig. $4 \mathrm{~b}$ shows the molar ratio of $\mathrm{H}_{2} \mathrm{~S}$ to organosulfur compounds as a function of thiophene conversion for pure thiophene, for

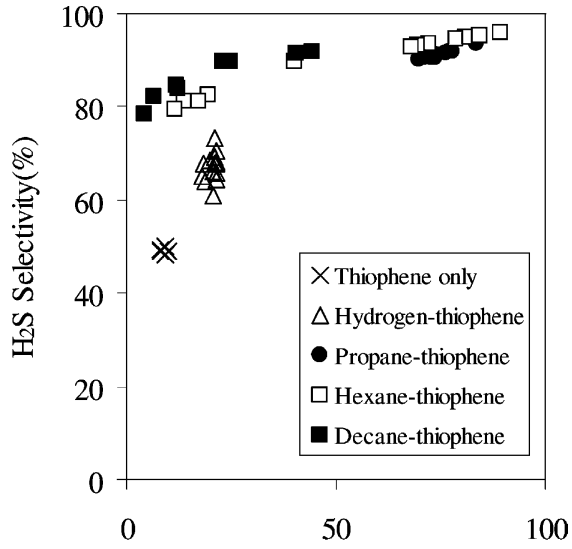

(a) Thiophene Conversion (\%)

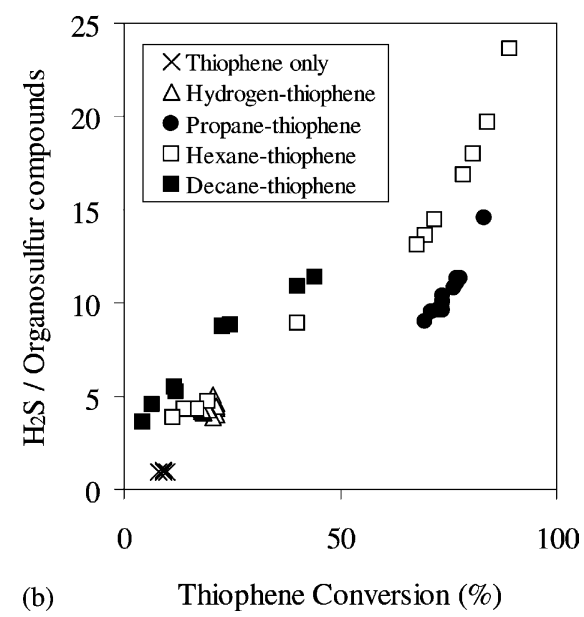

Fig. 4. (a) Hydrogen sulfide selectivity of alkane-thiophene reactions on H-ZSM5 (Si/Al $=14.5$ ) as a function of thiophene conversion: thiophene only $\left(773 \mathrm{~K}, 1 \mathrm{kPa} \mathrm{C}_{4} \mathrm{H}_{4} \mathrm{~S}\right.$, balance $\mathrm{He})$, hydrogen-thiophene $(773 \mathrm{~K}, 200 \mathrm{kPa}$ hydrogen, $1 \mathrm{kPa}$ $\mathrm{C}_{4} \mathrm{H}_{4} \mathrm{~S}$, balance $\left.\mathrm{He}\right)$, propane-thiophene $\left(773 \mathrm{~K}, 20 \mathrm{kPa} \mathrm{C}_{3} \mathrm{H}_{8}\right.$, $1 \mathrm{kPa} \quad \mathrm{C}_{4} \mathrm{H}_{4} \mathrm{~S}$, balance $\mathrm{He}$ ), hexane-thiophene $(673 \mathrm{~K}, 20 \mathrm{kPa}$ $\mathrm{C}_{6} \mathrm{H}_{14}, 1 \mathrm{kPa} \mathrm{C}_{4} \mathrm{H}_{4} \mathrm{~S}$, balance $\left.\mathrm{He}\right)$, decane-thiophene $(673 \mathrm{~K}$, $6 \mathrm{kPa} \mathrm{C}_{10} \mathrm{H}_{22}, 1 \mathrm{kPa} \mathrm{C}_{4} \mathrm{H}_{4} \mathrm{~S}$, balance $\mathrm{He}$ ). (b) Hydrogen sulfide/organosulfur compound molar ratio for alkane-thiophene reactions on H-ZSM5 $(\mathrm{Si} / \mathrm{Al}=14.5)$ as a function of thiophene conversion: thiophene only $\left(773 \mathrm{~K}, 1 \mathrm{kPa} \mathrm{C}_{4} \mathrm{H}_{4} \mathrm{~S}\right.$, balance $\left.\mathrm{He}\right)$, hydrogen-thiophene $\left(773 \mathrm{~K}, 200 \mathrm{kPa}\right.$ hydrogen, $1 \mathrm{kPa} \mathrm{C}_{4} \mathrm{H}_{4} \mathrm{~S}$, balance $\mathrm{He})$, propane-thiophene $\left(773 \mathrm{~K}, 20 \mathrm{kPa} \mathrm{C}_{3} \mathrm{H}_{8}, 1 \mathrm{kPa} \mathrm{C}_{4} \mathrm{H}_{4} \mathrm{~S}\right.$, balance $\mathrm{He})$, hexane-thiophene $\left(673 \mathrm{~K}, 20 \mathrm{kPa} \mathrm{C}_{6} \mathrm{H}_{14}, 1 \mathrm{kPa}\right.$ $\mathrm{C}_{4} \mathrm{H}_{4} \mathrm{~S}$, balance $\left.\mathrm{He}\right)$, decane-thiophene $\left(673 \mathrm{~K}, 6 \mathrm{kPa} \mathrm{C}_{10} \mathrm{H}_{22}\right.$, $1 \mathrm{kPa} \mathrm{C}_{4} \mathrm{H}_{4} \mathrm{~S}$, balance $\mathrm{He}$ ). 

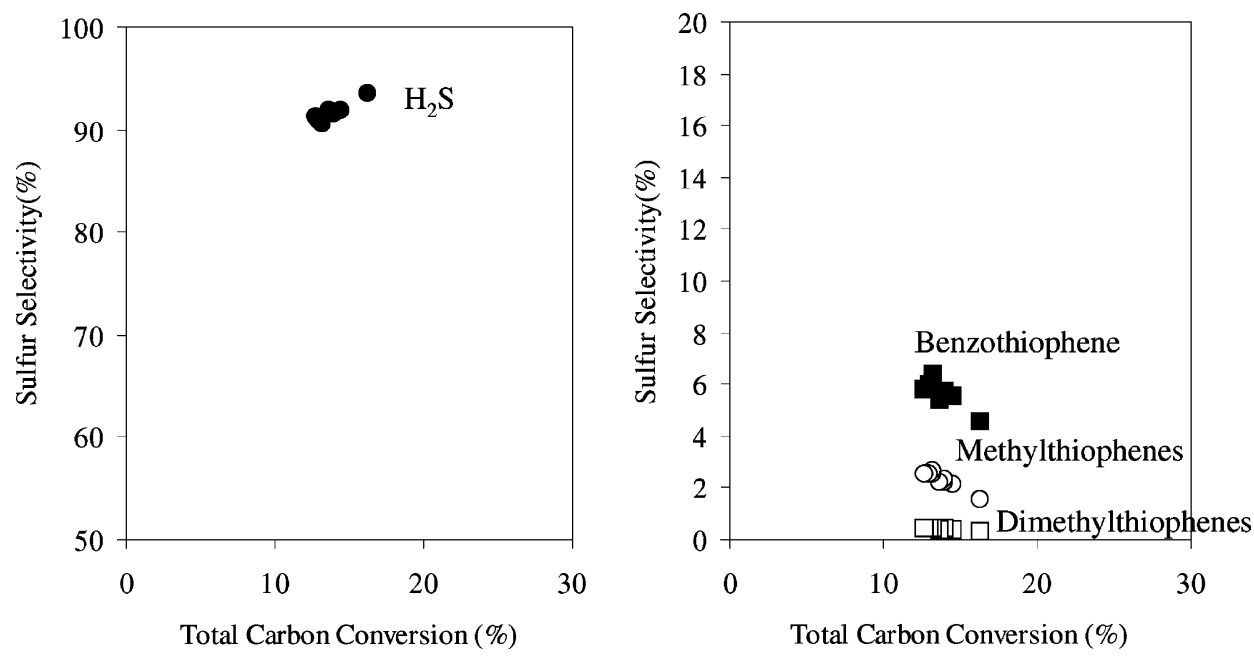

Fig. 5. Product sulfur selectivity of propane-thiophene reactions on H-ZSM5 ( $\mathrm{Si} / \mathrm{Al}=14.5$ ) as a function of total carbon conversion: $773 \mathrm{~K}, 20 \mathrm{kPa} \mathrm{C}_{3} \mathrm{H}_{8}, 1 \mathrm{kPa} \mathrm{C} \mathrm{H}_{4} \mathrm{~S}$, balance $\mathrm{He}$.

the three alkane co-reactants used in this study, and for $\mathrm{H}_{2}$ co-reactants. This ratio was larger with $\mathrm{H}_{2}$ co-reactants than with pure thiophene feeds; it was even larger when alkanes were used as co-reactants. This selectivity ratio increased with increasing alkane chain length, apparently because of the higher reactivity and hydrogen transfer rates prevalent when higher alkanes are used as co-reactants, which is also reflected in the observed increase of thiophene desulfurization rates with increasing alkane chain length (Table 1).

The detailed sulfur speciation among reaction products are shown in Figs. 5-7 for each alkane-thiophene mixture as a function of total (alkane + thiophene) reactant conversion. For all alkane co-reactants, hydrogen sulfide is the predominant sulfur compound
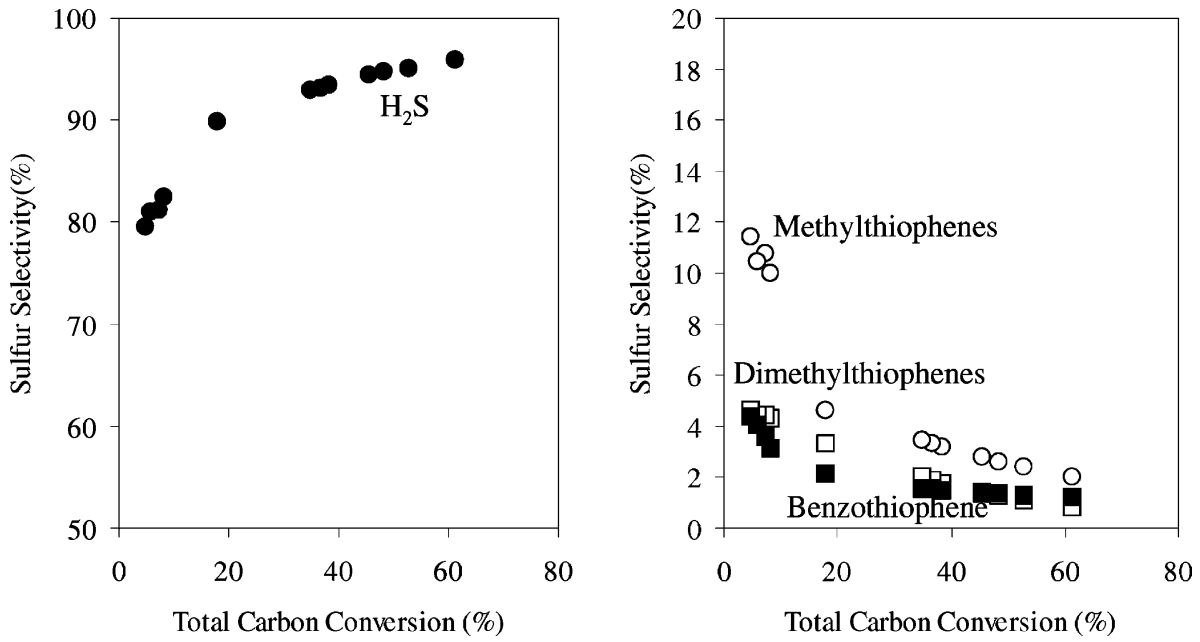

Fig. 6. Product sulfur selectivity of hexane-thiophene reactions on H-ZSM5 ( $\mathrm{Si} / \mathrm{Al}=14.5)$ as a function of total carbon conversion: $673 \mathrm{~K}$, $20 \mathrm{kPa} \mathrm{C}_{6} \mathrm{H}_{14}, 1 \mathrm{kPa} \mathrm{C}_{4} \mathrm{H}_{4} \mathrm{~S}$, balance He. 

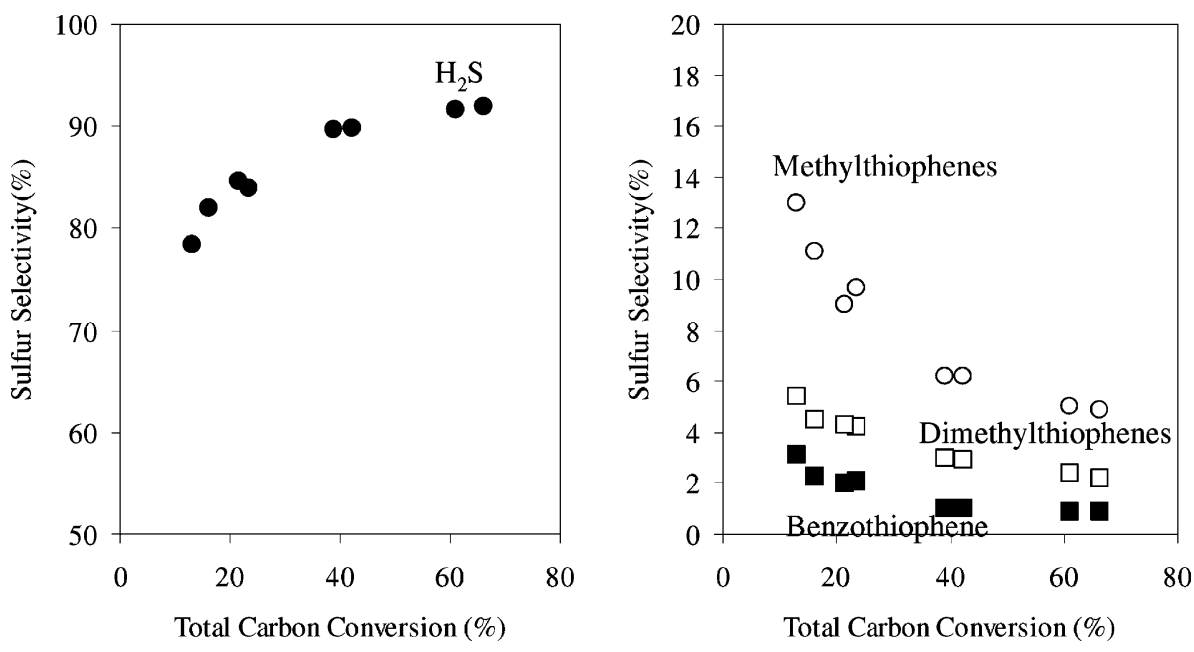

Fig. 7. Product sulfur selectivity of decane-thiophene reactions on $\mathrm{H}-\mathrm{ZSM} 5(\mathrm{Si} / \mathrm{Al}=14.5)$ as a function of total carbon conversion: $673 \mathrm{~K}$, $6 \mathrm{kPa} \mathrm{C}_{10} \mathrm{H}_{22}, 1 \mathrm{kPa} \mathrm{C} \mathrm{C}_{4} \mathrm{~S}$, balance He.

formed, but small amounts of organosulfur compounds (methylthiophene, dimethylthiophene, and benzothiophene) are also formed via alkylation of thiophene or via bimolecular Diels-Alder reactions (Figs. 5-7). With propane co-reactants, benzothiophene was the most prevalent organosulfur compound, while hexane and decane co-reactants led to the predominant formation of alkyl-thiophenes (Figs. 5-7). The lower reactivity of propane compared with that of larger alkanes led to lower rates for the scavenging of thiophene-derived precursors, which are required as intermediates in the formation of larger organosulfur compounds. With all three alkane co-reactants, the selectivity to methylthiophene is greater than that for dimethylthiophene (Figs. 5-7) and the $\mathrm{H}_{2} \mathrm{~S}$ selectivity increases with increasing conversion at the expense of the formation of organosulfur compounds (Figs. 5-7). This indicates that organosulfur compounds react further with increasing residence time to form hydrogen sulfide and hydrocarbon products in secondary desulfurization reactions.

\section{Conclusions}

Propane, $n$-hexane, and $n$-decane were used as an effective co-reactant in the selective desulfurization of thiophene to form hydrogen sulfide and hydrocar- bons on H-ZSM5 at $673 \mathrm{~K}$. Thiophene desulfurization rates, rate constants, and deactivation rates increased with increasing alkane chain size. The higher reactivity of larger alkanes leads to their more effective use as a source of hydrogen and hydrogen-rich intermediates, which are involved in reactions with unsaturated fragments formed in thiophene desulfurization reactions. All three alkanes are also more effective desulfurization co-reactants than $\mathrm{H}_{2}(100-200 \mathrm{kPa}, 773 \mathrm{~K})$, even when $\mathrm{H}_{2}$ dissociation sites, in the form of $\mathrm{Zn}$ cations, are introduced onto H-ZSM5 catalysts during synthesis. The presence and scavenging reactions of thiophene molecules do not alter the nature of alkane reaction pathways on H-ZSM5, but the selectivity for alkane conversion to aromatics increases as a result of the selective reaction of alkane-derived species with unsaturated fragments formed in thiophene decomposition and desulfurization reactions.

\section{Acknowledgements}

This work was supported by the National Science Foundation (CTS-96-13632) under the technical supervision of Dr. Geoffrey Prentice as part of the NSF-EPA partnership. One of the authors (T.W.) acknowledges the financial support of the Japan Cooperation Center, Petroleum and Nippon Oil 
Corporation for his research activities at the University of California at Berkeley.

\section{References}

[1] S.Y. Yu, W. Li, E. Iglesia, J. Catal. 187 (1999) 257.

[2] W. Li, S.Y. Yu, E. Iglesia, Stud. Surf. Sci. Catal. 130 (2000) 899.

[3] W. Li, S.Y. Yu, E. Iglesia, J. Catal. 203 (2001) 175.

[4] W. Li, S.Y. Yu, E. Iglesia, J. Catal. 207 (2002) 31.

[5] W.J.J. Welters, T.I. Koranyi, V.H.J. de Beer, R.A. van Santen, Stud. Surf. Sci. Catal. 75 (1993) 1931.

[6] W.J.J. Welters, V.H.J. de Beer, R.A. van Santen, Appl. Catal. 119 (1994) 253

[7] W.J.J. Welters, G. Vorbeck, H.W. Zandbergen, J.W. de Haan, V.H.J. de Beer, R.A. van Santen, J. Catal. 150 (1994) 155.

[8] T.I. Koranyi, A. Jentys, H. Vinek, Stud. Surf. Sci. Catal. 94 (1995) 582.

[9] M. Sugioka, C. Tochiyama, Y. Matsumoto, F. Sado, Stud. Surf. Sci. Catal. 94 (1995) 544.
[10] M. Sugioka, F. Sado, T. Kurosaka, X. Wang, Catal. Today 45 (1998) 327.

[11] M. Sugioka, S. Morishita, T. Kurosaka, A. Seino, M. Nakagawa, S. Namba, Stud. Surf. Sci. Catal. 125 (1999) 531.

[12] A. Corma, M.S. Grande, P. Gullbrand, C. Martinez, Abstr. Paper Am. Chem. Soc. 218 (1999) 33.

[13] A. Corma, C. Martinez, G. Ketley, G. Blair, Appl. Catal. A 208 (2001) 135.

[14] A. Corma, P. Gullbrand, C. Martinez, Stud. Surf. Sci. Catal. 134 (2001) 153.

[15] R.F. Wormsbecher, D.S. Chin, B. Patrose, R.R. Gatte, T.G. Albro, R.H. Harding, Abstr. Paper Am. Chem. Soc. 203 (1992) 7.

[16] R.H. Harding, R.R. Gatte, T.G. Albro, R.F. Wormsbecher, Abstr. Paper Am. Chem. Soc. 205 (1993) 9.

[17] J.A. Biscardi, E. Iglesia, J. Phys. Chem. B 102 (1998) 9284.

[18] R.W. Borry, Y.H. Kim, A. Huffsmith, J.A. Reimer, E. Iglesia, J. Phys. Chem. B 103 (1999) 5787.

[19] W. Li, S.Y. Yu, G.D. Meitzner, E. Iglesia, J. Phys. Chem. B 105 (2001) 1176.

[20] X. Saintigny, R.A. van Santen, S. Clemendot, F. Hutschka, J. Catal. 183 (1999) 107. 